\title{
抵抗溶接条件パラメーターeqr の提案 \\ THE PRESENTATION OF RESISTANCE SPOT WELDING PARAMETER “EQR” THAT DETERMINES WELDED JOINT TENSILE STRENGTH
}

\author{
野原和宏*, 山本雅 也**, 中込忠男***, 青 木博 文**** \\ Kazuhiro NOHARA, Masaya YAMAMOTO, Tadao NAKAGOMI \\ and Hirofumi AOKI
}

\begin{abstract}
This study made it clear that the following parameter"eqr" can determine the tensile shear strength of resistance spot welded joint. This parameter "eqr" represents the residual heat quantity of the contact part of the welded plates after welding time. It includes spot welding current, welding time, electrode force, electrode tip diameter and welded plate thickness.

It was made it clear by experiments that the parameter"eqr" can be applied to estimate the tensile shear strength of uncoated steel and hot-dip coated steel that were the carbon steels strength class less than $490 \mathrm{~N} / \mathrm{mm}^{2}$.
\end{abstract}

\section{Keywords :Residual heat quantity,Welding current,Welding time,Electrode force,Electrode tip diameter,Tensile shear strength 残留熱量, 溶接電流, 通電時間, 電極加圧力, 電極先端直径, 引張せん断強度}

\section{1. はじめに}

抵抗溶接の 1 点当たりの許容せん断力を求める力法が、建築基準 法施行規則第 1 条の三第一項第一号イ、同号口(1)及び同号口(2)の 認定に係る性能評価業務方法書に示寸 “(別記)建築物の保有水平耐 力及び部材の許容耐力等の評価方法”で示されている。その中で実 験で求めた保証強度の $1 / 3$ を長期許容せん断力上している。

杖ッ愹接の引張せん断強度に関する従来の検討 1) 3)では、㐫る限 られた溶接条件（電極先端径、圧力、電流、通電時間）での引張せ ん断強度の実験式しかない。

これらの溶接諸条件を一つのパラメーターとして表現でき、そのパラメー 夕ーを用いて引張せん断強度を整理できれば、実験量もへり過去の実 験データから引張せん断強度も推定することができる。

このパラメーターを抵抗溶接条件パラメーター eqr として提案し、その妥当 性を明らかにし、板厚 $1.6 \mathrm{~mm}$ から $4.5 \mathrm{~mm}$ の範囲で通常適用される溶 接条件範囲の引張せん断強度を実験式化した。

\section{2. 同一板厚同士の抵抗溶接の場合}

2. 1 抵抗溶接条件パラメーターの考え方

2. 1 . 1 発熱を支配する因子の導出

抵抗溶接部の発熱は、電極上板や板板間の接触抵抗および板内部 の抵抗によるジュール発熱と電極や被溶接物への熱の逃散や空気中へ の熱の放散で決定されるが、発熱を支配する因子を考える上では熱
の逃散・放熱は無視して考える。

（1）通電域を考慮しない場合の発熱支配因子

$$
\begin{aligned}
& q t=I \cdot V \cdot t i=I \cdot(I \cdot R) \cdot t i=I \cdot\left(I \cdot P^{n}\right) \cdot t i=I^{2} \cdot P^{n} \cdot t i \cdots(1) \\
& q t: \text { 全発熱量を表す因子 } n: \text { 指数 } \\
& I: \text { 電流 } R: \text { 電極間抵抗 } t i: \text { 通電時間 } P: \text { 加圧力 }
\end{aligned}
$$

式 (1) で電極間抵抗を板板間の接触抵抗が主と考え、 $R$ を加圧力の $n$ 乗とした。その根拠は従来からの教材 ${ }^{4)}$ に一般的に表現されてい る上ころより採用した。加圧力が一定でも電極先端径が変われば健 全な抵抗溶接ができたり、溶接されなかったりする現実を考えると 式(1)は発熱支配因子とは成り得ない。

（2）通電域を考慮した場合の発熱支配因子

通電面積を $S c$ として単位面積当の接触抵抗がその部分の圧力の 強さ $(P / S C)$ の $n$ 乗であると仮定すると発熱を支配する因子は次の ようになる。

$$
\begin{aligned}
q a & =(I / S C) \cdot\left\{(I / S C) \mathrm{x}(P / S C)^{n}\right\} \cdot S c \cdot t i \\
& =I^{2} / S C \cdot(P / S C)^{n} \cdot t i \quad \cdots(2)
\end{aligned}
$$

（3）通電域の発熱と通電終了時の通電域内残留熱量を考慮した 発熱支配因子

前式 (2) では通電域内の発熱量を支配する因子ではあるが、時間を かけて抵抗溶接した場合に通電域外の面内に熱が逃げた場合を表現 することができない。そこで、通電時間経過後に残存している熱量 の割合を残存率 $r f$ と寸る。通電域内の残存熱量は次式となる。

\footnotetext{
本論文は2010年 9 月に日本建築学会学術講演会(北陸)において発表した内容を基に加筆したものである。

* 積水化学工業(侏住宅技術研究所 所長 ·博士(工学) Director, Housing Technology Institute, Sekisui Chemical Co., Ltd., Dr. Eng.

** 積水化学工業(株) 主任研究員

*** 信州大学建築学科 教授・博士 (工学)

Senior Research Engineer, Sekisui Chemical Co., Ltd.

Prof., Dept. of Architecture, Shinshu University, Dr. Eng.

横浜国立大学 名誉教授・博士 (工学)

Emeritus Prof., Yokohama National University, Dr. Eng.
} 
$q r=I^{2} / S c \cdot(P / S c)^{n} \cdot t i \cdot r f \quad \cdots(3)$

残存率 $r f$ は次のように考える。本来抵抗溶接はある時間をかけて 発熱させて溶接するわけであるが、残存率を求める為に電極の軸方 向に瞬間線熱源が投与されたと仮定し、通電時間後に通電域内に残 された熱量の比を残存率 $r f$ とする。

瞬間線熱源 $(q)$ が与えられた時の温度上昇は次式となる。

$T=(q / \mathrm{c} \rho) \exp \left\{-r^{2} /(4 \mathrm{k} \cdot t i)\right\} /(4 \pi \mathrm{k} \cdot t i)$ $\cdots(4)$

$q$ : 瞬間線熱源投与熱量 $r:$ 熱源からの距離

$\mathrm{k}$ : 熱拡散率 $\mathrm{c}$ : 比熱 $\rho$ : 密度 $t i$ : 通電時間

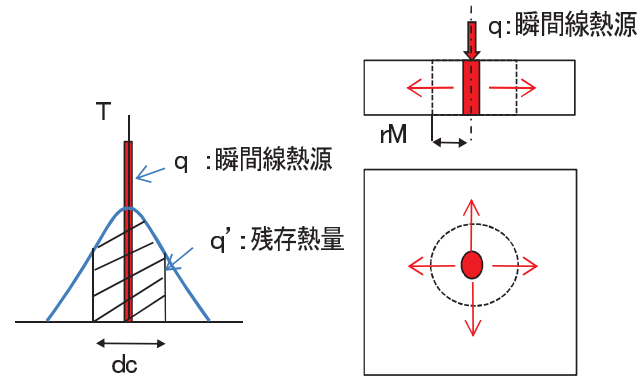

図 1 残存熱量の考え方

図 1 に示寸ように、式(4)の瞬間線熱源投与後通電時間 $t i$ 後に半 径 $r M$ 内に残る熱量を次のように求める。

半径 $r M$ に時間 $t i$ 後に残る熱量 $q$ '求める。

$$
q^{\prime}=\int_{0}{ }^{r M} T \cdot c \rho \cdot 2 \pi r d r \cdot \cdots(5)
$$

式(4)を式(5)に代入して積分を実行すると次式が求められる。

$$
q^{\prime}=q \cdot\left\{1-\exp \left(-r M^{2} / 4 \mathrm{k} t i\right)\right\}
$$

$r M=d c / 2 （ d c$ : 通電面積の直径）を代入する。

$$
\begin{aligned}
& q^{\prime}=q \cdot\left\{1-\exp \left(-d c^{2} / 16 \mathrm{k} \cdot t i\right)\right\} \\
& r f=q, \quad / \mathrm{q}=1-\exp \left(-d c^{2} / 16 \mathrm{k} \cdot t i\right) \quad \cdots(6)
\end{aligned}
$$

通電域を考慮し、残存熱量を考慮した発熱量の支配因子は式 (3) に式(6)で表される $r f$ を代入すればよい。

\section{1.2 電極先端径 $(\mathrm{de})$ と通電径 $(\mathrm{dc})$ の関係}

2.1.1の抵抗溶接部の発熱量を支配する因子の中で示した通 電域の直径 $d c$ について説明する。前述したように板板間の発熱が接 合されるか否かに大きくかかわる。その発熱は板板間の接触抵抗に 大きく影響される。したがって、板板間の接触状態が先端電極径・

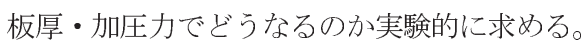

図 2 に示寸ように板板間に感圧紙を挟んで、圧力の作用している 部分の直径を計測する。感圧紙の仕様、電極先端径、板厚、作用さ せる加圧力等実験条件を表 1 に示す。

感圧紙による圧力測定方法を図 2 に示寸。図 3 は感圧紙の色調变 化とそのグレースケール処理結果を示す。左側怔感圧紙の色調変化、右側 はグレースケール処理したものである。グレースケール処理とは力ラ一画像を（赤 x0.3 +緑 x0. 59 +青 x0.11）で变換し、その階調で接触強さを表した ものである。図3の右側の結果を数值的に表現すると図 4 のように なる。

図 5 は図 4 に示寸圧力分の圧力の立ち上がる部分の直径 $d c 1$ と板 厚、電極先端径の関係を種々の加圧力の時も含めて表したものであ る。この $d c 1$ を式 (6) での通電径 $d c$ とする。 $d c$ は次式で表される。 $d c=0.5 \cdot d e+2.5 \cdot t \quad \cdots(7)$

表 1 感圧紙による板板間圧力作用域の測定諸条件

\begin{tabular}{|l|l|}
\hline 項目 & 仕様および実験条件範囲 \\
\hline 感圧紙 & 富士フイルム製プレイケール $\left(10 \sim 50 \mathrm{~N} / \mathrm{mm}^{2}\right)$ \\
\hline 板厚 & $1.6 、 2.3 、 3.2 、 4.5 \mathrm{~mm}$ \\
\hline $\begin{array}{l}\text { 先端電極径 } \\
\text { (曲率半径) }\end{array}$ & $\begin{array}{l}\text { 直径 } 6,9,11,14 \mathrm{~mm} \\
\text { (先端曲率半径 } 75 \mathrm{~mm} \text { ) }\end{array}$ \\
\hline $\begin{array}{l}\text { 加圧力の強さ } \\
\text { (加圧力/電極先端投 } \\
\text { 影面積) }\end{array}$ & $40.25 、 52.0 、 61.56 、 70.03$ \\
\hline
\end{tabular}

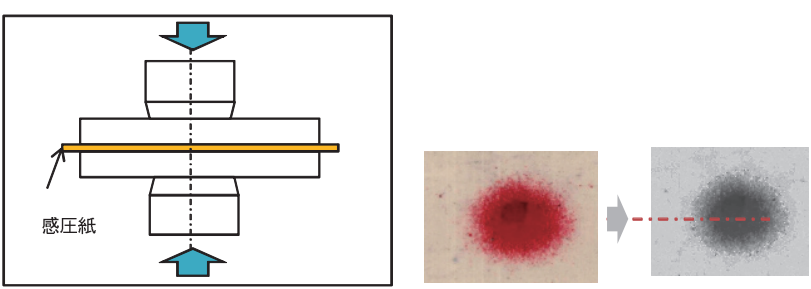

図 2 感圧紙による加圧実験模式図 図 3 感圧紙とグレースケール処理

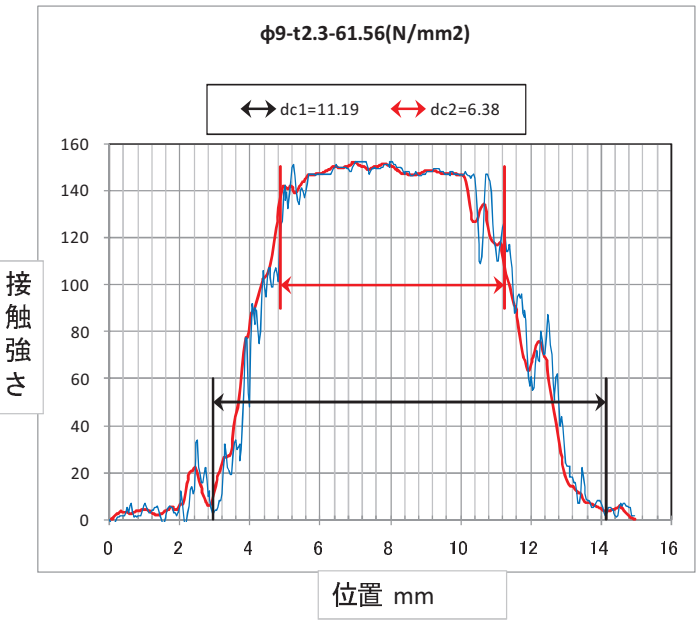

図 4 圧力分布例

$\mathrm{de} / \mathrm{t}-\mathrm{dc} 1 / \mathrm{t}$

$\mathrm{t} 1.6-52.00 \quad \square \mathrm{t} 1.6-61.56 \quad \mathrm{t} 1.6-72.00 \quad \Delta \mathrm{t} 2.3-40.25$

$\Delta \mathrm{t} 2.3-52.00 \Delta \mathrm{t} 2.3-61.56 \Delta \mathrm{t} 2.3-70.03 \quad \mathrm{t} 3.2-40.25$

t3.2-61.56 t3.2-70.03 $\times$ t4.5-40.25 $\times+4.5-61.56$ $\times \mathrm{t} 4.5-70.03$

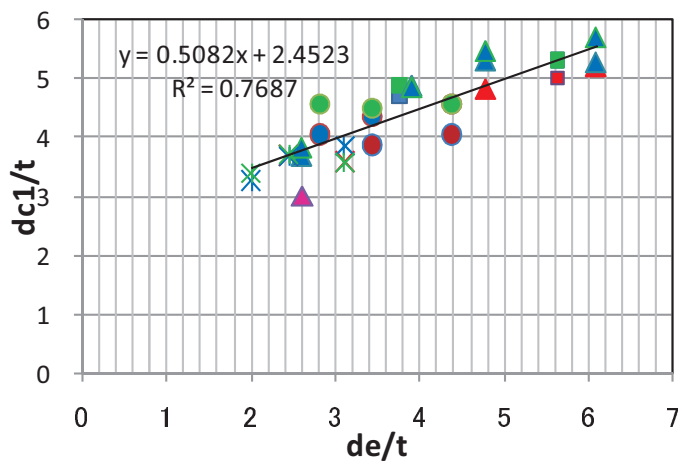

図 5 接触部の直径 $\mathrm{dc} 1$ と板厚 $\mathrm{t}$ 上電極先端径 de の関係 


\section{2 同一板厚の場合の発熱支配因子 $q r$ の妥当性実証}

前節で抵抗溶接時の発熱を支配する因子として式(1)、(2)、(3)の 3つを挙げた。どの因子が最も実用的に使えるかを実験的に求める。 本章では同一板厚のメッキ鋼板について検討する。

\section{2. 1 実験条件}

（1）試験体形状、寸法、供試材料の機械的性質

実験に用いる試験体形状を図 6 亿示す。その寸法諸元を表 2 に機 械的性質を表 3 に示寸。材料は $400 \mathrm{~N} / \mathrm{mm}^{2}$ 級の溶融亜鉛一 $6 \% \mathrm{~A} 1-3 \% \mathrm{Mg}$ 合金メッキ鋼板で、公称目付けが両面 $180 \mathrm{~g} / \mathrm{m}^{2}$, 最小目付け両面 $140 \mathrm{~g} / \mathrm{m}^{2}$ である。

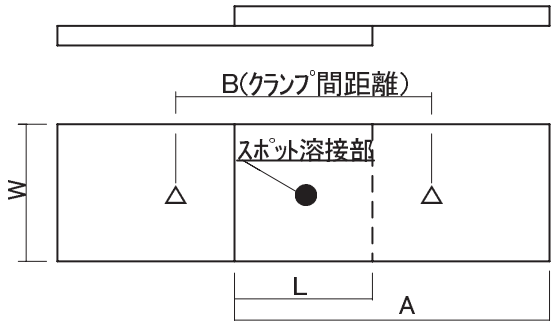

図 6 試験片形状

表 2 試験体寸法

表 3 供試験材料の機械的性質

\begin{tabular}{|c|c|c|c|c|c|c|c|c|}
\hline 板匽 $(\mathrm{mm})$ & 板幅 $($ W' & 重好代(L) & 試験片長さ(A) & 行次間距離(B) & 板厚 $(\mathrm{mm})$ & $Y_{p}(\mathrm{~N} / \mathrm{mm} 2)$ & $\mathrm{Ts}(\mathrm{N} / \mathrm{mm} 2)$ & $E L(\%)$ \\
\hline $1.6 \times 1.6$ & 60 & 45 & 138 & 105 & $\mathrm{t} 1.6$ & 349 & 467 & 34.2 \\
\hline $2,3 \times 2,3$ & 90 & 60 & 160 & 120 & $\mathrm{t} 2.3$ & 306 & 445 & 35.2 \\
\hline $3.2 \times 3.2$ & 90 & 60 & 160 & 120 & $t 3.2$ & 304 & 455 & 36.5 \\
\hline $4,5 \times 4,5$ & 90 & 60 & 160 & 120 & $\mathrm{t} 4.5$ & 333 & 440 & 34.1 \\
\hline
\end{tabular}

\section{（2）抵抗溶接諸条件}

溶接機は 2 種の交流溶接機を用いた、電極は CR 型で先端曲率半径 $75 \mathrm{~mm}$ 、電極先端径を 6 〜 $14 \mathrm{~mm}$ の間で 5 種とした (表 4,5 参照)

表 4 溶接機 A の仕様

\begin{tabular}{|c|c|c|c|}
\hline 項目 & 製造元 & 型式 & 電極 \\
\hline タイマー & \multirow{4}{*}{$\begin{array}{l}\text { Pana } \\
\text { sonic }\end{array}$} & YF-0201Z2 & 吅么銅、先端径 $\phi 6,9$ \\
\hline בンタタタ & & REU80003 & \\
\hline & & 固定式 & 11 \\
\hline ガン & & RTU80001 & \\
\hline モ二タ & ダイヘ & RE-M1 & \\
\hline
\end{tabular}

表 5 溶接機 B の仕様

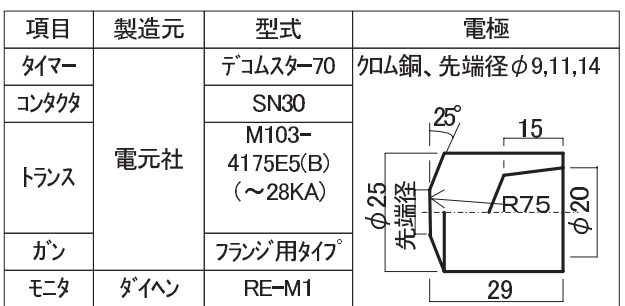

表 6 溶接条件水準

\begin{tabular}{|c|c|c|c|c|c|}
\hline 鋼種 & 板厚 & 電極先端径 & $\begin{array}{l}\text { 電極先端単 } \\
\text { 位面積当の工 } \\
\text { ネルキ" } \quad\left(\mathrm{kA}^{2} \text {. }\right. \\
\left.\mathrm{s} / \mathrm{mm}^{2}\right)\end{array}$ & $\begin{array}{l}\text { 電極先端単 } \\
\text { 位面積当の } \\
\text { 加 圧 力 } \\
(\mathrm{N} / \mathrm{mm} 2)\end{array}$ & $\begin{array}{l}\text { 溶 接 } \\
\text { 機・表 } \\
4,5 \text { 参 } \\
\text { 照 }\end{array}$ \\
\hline \multirow{5}{*}{$\begin{array}{l}\text { ZAM } \\
400 \\
\mathrm{~N} / \mathrm{mm}^{2}\end{array}$} & $1.6 \times 1.6$ & $\phi 6,9$ & $1.7,2.1$ & 52,62 & \multirow[t]{2}{*}{ A } \\
\hline & 2. $3 \times 2.3$ & $\phi 6,9$ & 同上 & 同上 & \\
\hline & 同上 & $\phi 9,11,14$ & 2. $0,2.6,3.3$ & $41,62,70$ & \multirow[t]{3}{*}{ B } \\
\hline & $3.2 \times 3.2$ & 同上 & $2.2,2.6,3.3$ & 同上 & \\
\hline & $4.5 \times 4.5$ & 同上 & $2.5,3.2,4.0$ & 同上 & \\
\hline
\end{tabular}

ZAM: 溶融亜鉛- $6 \%$ A1-3\%Mg 溶融火少鋼板を表寸

溶接条件水準を表 6 に示す。同一条件のサンプル数は 3 である。 表 6 に示寸溶接条件水準で抵抗溶接を行い引張試験を実施した。

\section{2.2 実験結果および考察}

引張試験結果を前節で提示した抵抗溶接時の発熱量を支配する 因子 3 つで整理を行い実用上どの支配因子が実用的かを検討寸る。 今回実施した $1.6 \mathrm{~mm}$ から $4.5 \mathrm{~mm}$ の板厚で代表例として $3.2 \mathrm{~mm}$ の場合 の結果を図 7 に示寸

図 7 は板厚 3. $2 \mathrm{~mm}$ の場合の式 (1)、(2)、(3)のそれぞれの場合の発熱 を支配する因子と引張せん断強度との関係を示している。なお、発 熱支配因子を計算する時の熱拡散係数 $\mathrm{k}$ は鋼の $100^{\circ} \mathrm{C}$ の值すなわち $\mathrm{k}=18.2 \mathrm{~mm}^{2} / \mathrm{sec}$ を用いた。指数 $\mathrm{n}$ はマ什スの值で引張せん断強度と よい相関上なる值を用いた。これらのグラフによると式(3) の発熱因 子がうまく引張せん断強度を整理できることが解る。他の板厚 1.6, 2.3 $4.5 \mathrm{~mm}$ の場合も同様で式(3) で整理したものを図 8 に示寸。

(1)通電域を考慮しない発熱支配因子で整理した場合

- de=9,ti=1.82 प de=9,ti=1.49 de=9,ti=1.24

- de=11,ti=2.17 $\square \mathrm{de}=11, \mathrm{ti}=1.65 \quad \mathrm{de}=11, \mathrm{ti}=1.30$

- $\mathrm{de}=14, \mathrm{ti}=2.25 \quad \square \mathrm{de}=14, \mathrm{ti}=1.75$ de=14,ti=1.40

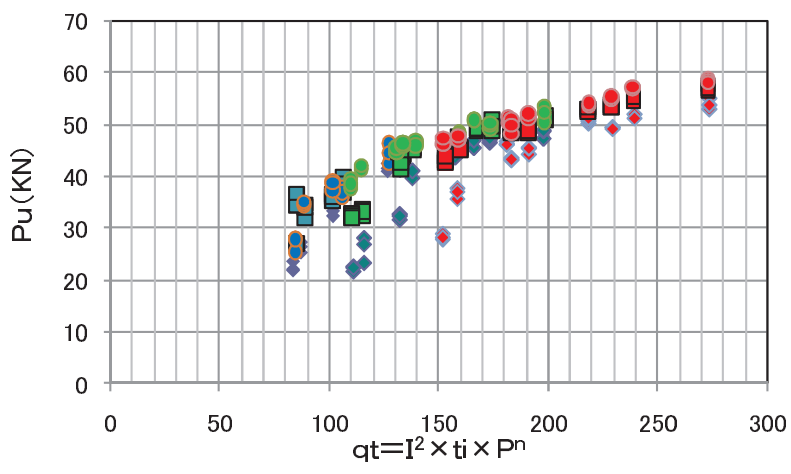

(a)式（1）のqtを用いた場合

図 7 発熱を支配する因子（式(1)（2）(3)）上引張せん断強度 $P u$ の関係 $\left(t=3.2 \mathrm{~mm}\right.$ 、熱拡散係数 $\mathrm{k}=18.2 \mathrm{~mm}^{2} / \mathrm{sec}$, 指数 $\left.n=-1 / 3\right)$ 


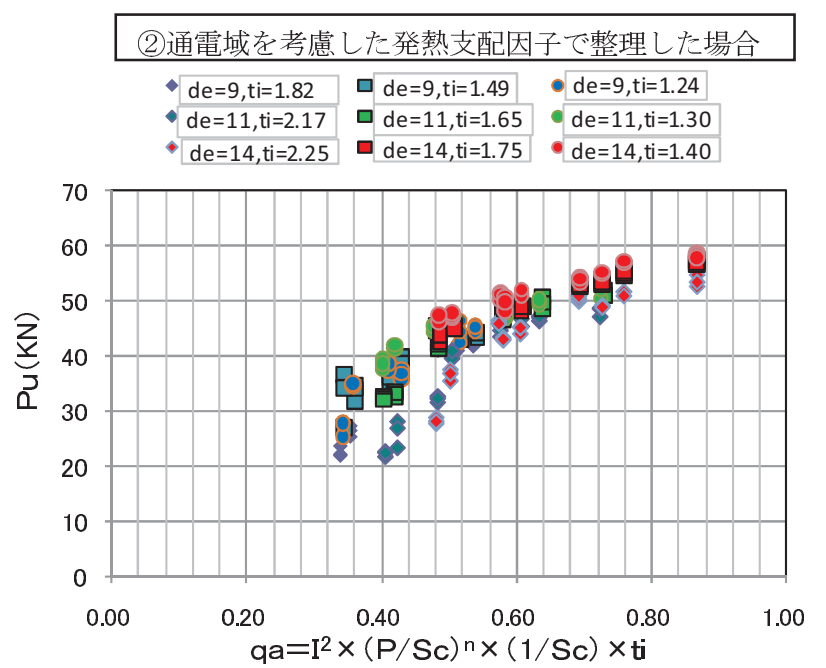

(b)式（2）のqaを用いた場合

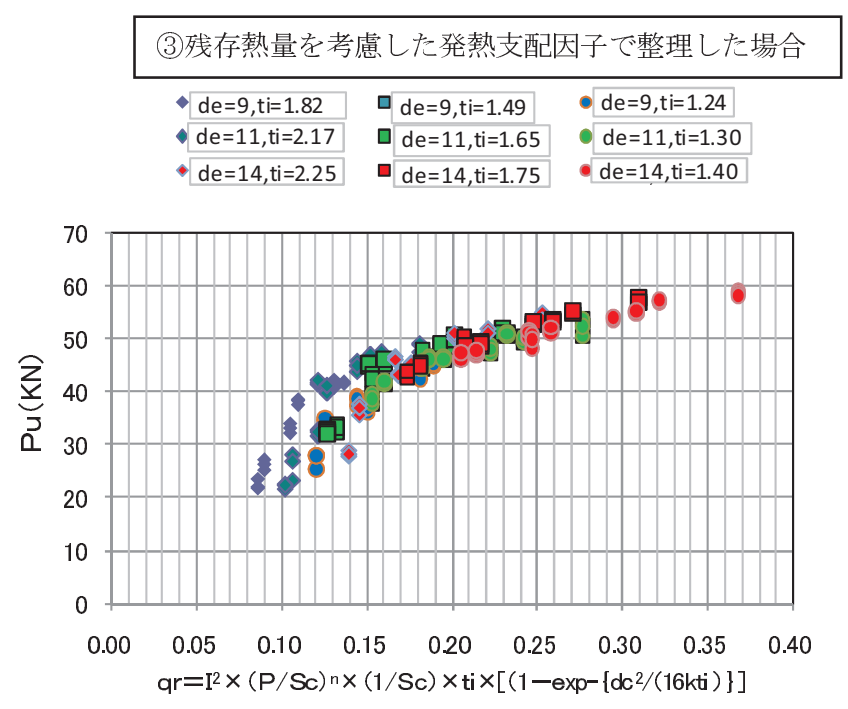

(c)式（3）のqrを用いた場合

図 7 発熱を支配する因子 (式 (1) (2) (3)) 上引張せん断強度 $P u$ の関係 $\left(t=3.2 \mathrm{~mm}\right.$ 、熱拡散係数 $\mathrm{k}=18.2 \mathrm{~mm}^{2} / \mathrm{sec}$, 指数 $\left.n=-1 / 3\right)$

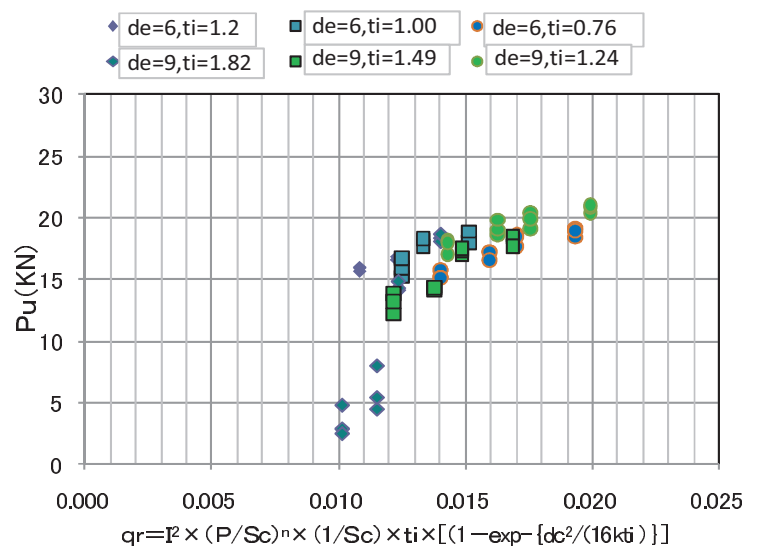

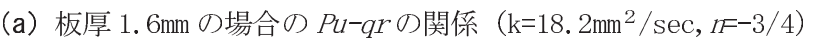

図 8 各板厚での Pu-qrの関係

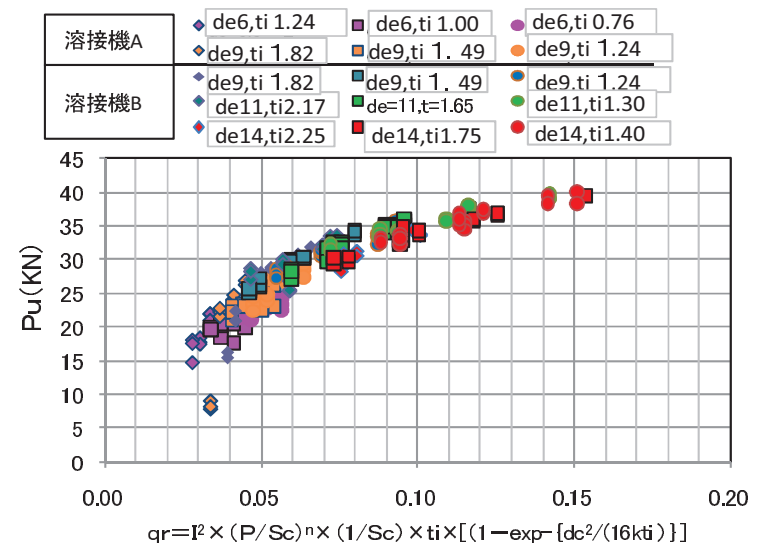

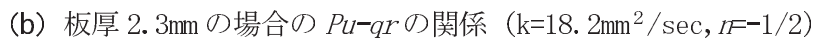

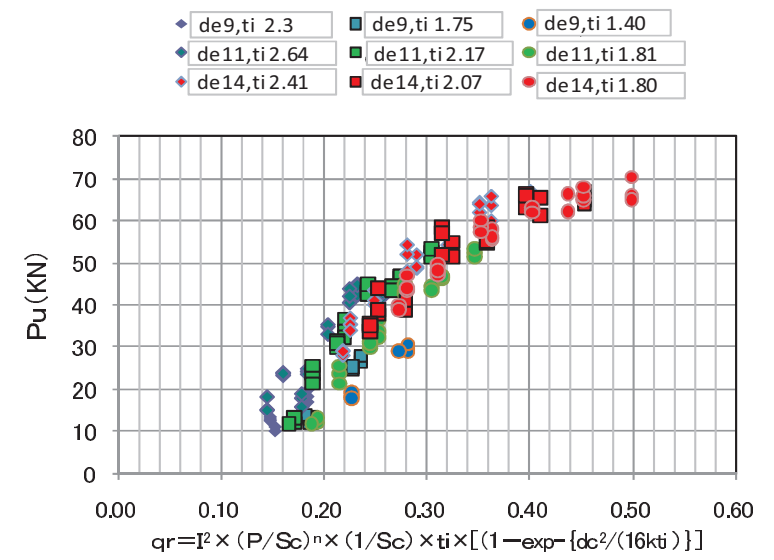

（c）板厚 $4.5 \mathrm{~mm}$ の場合のPu-qrの関係 $\left(\mathrm{k}=18.2 \mathrm{~mm}^{2} / \mathrm{sec}, n=-1 / 4\right)$

図 8 各板厚での Pu-qrの関係

図 7、図 8 の結果より、板厚 1.6, 2.3, 3.2, 4. 5mm の同一板厚同士 の種々の抵抗溶接条件において、式(3)で表す発熱の支配因子 $q r$ で 引張せん断強度が整理できることが解る。各板厚とも $q r$ のさい側 で多少バラ゙扫大きいが、引張せん断強度の下限值設定したり、qr の範囲を規定することで引張せん断強度の実験式化に利用できると 考えられる。

\section{3.メッキ、非メッキおよび強度レベルが異なる同一板厚の抵抗 溶接の場合}

前章では $400 \mathrm{~N} / \mathrm{mm}^{2}$ 級のメッ鋼板の同一板厚同士の抵抗溶接につい て、発熱支配因子 $q r$ の有効性を示した。本章では、非归の場合や 強度いベルが異なった場合について、発熱支配因子 $q r$ 修正について 検討する。

\section{1 発熱支配因子 $q r$ の非烽、異なる強度いベルの材料への展開}

\section{1， 1 非メッキ材への発熱支配因子 grの展開拡大}

前章に示した式(3)の qr の意味を説明する為に図 9 に模式図と 伴に再掲した。 


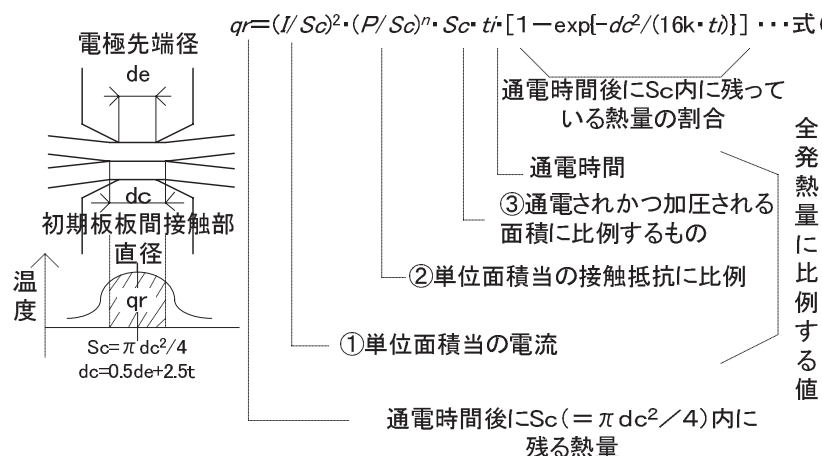

図 9 発熱因子 $q r$ の意味の説明図

ここで、図 9 で式(3) qr の物理的意味を説明する。溶接部全体の 発熱㤆板板間の接触抵抗による発熱と被溶接材の固有抵抗による発 熱が主なものである。被溶接材の界面が接合されるか否かは界面近 傍の発熱が十分か否かである。そこで、接合界面の接触抵抗による 発熱に注目した。

図 9 のSc は接触部の面積で1 1 は接触部の電流密度の 2 乗、(2)の) 内は加圧力を接触部の面積で除したの圧力の強さである。接触抵抗 は圧力の強さの $\mathrm{n}$ 乗 ${ }^{4)}$ なので、(1)と(2)積が単位時間・単位面積当 の発熱である。それらに(3)に示寸接触部の面積 $S c$ を掛けると接触抵 抗による単位時間の発熱量全体が求められる。それらに通電時間 $t i$ を掛けると接触抵抗による全発熱量が求められる。いくら発熱量が 多くても被溶接材の板表面に平行方向に逃げる熱は接合に寄与しな い。そこで前述した通電時間経過後に接触域内に残留する熱量の比 率を掛けて $q r$ として定義した。

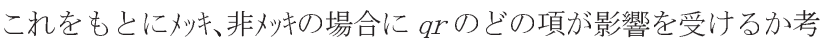
えてみる。

メッキ材を抵抗溶接する場合上非妇材を溶接する場合に経験寸るの は、同一溶接条件でも仯材の強度は低くなるという事である。定性 的には性搈けて電流密度が下がるであるうということであるが、 図9の各項について考える。

図 9 に示寸(1)の項は電流密度の項で州の場合電流密度が下がり、 非メッキの場合はメッキに比べ電流密度は高いものとなる。(2)項は単位 面積当たりの接触抵抗に影響及ぼす項であるが、メッキの溶融で通電領 域が増えても単位面積当たりの接触抵抗が変化するわけではない。 (3)の項は通電がされかつ加圧される領域に比例する項である。かッキ の溶融で通電域はかわるが加圧領域が変わるわけではない。よって、 メッキの有無に影響しない。最終項の残留熱量の割合は板表裏面に平行

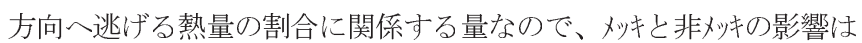
全く受けない。

以上の考察から、轩と非烧の差を図 9 に示寸式(3)の(1)の項目に 反映させる。よって、妙と非烧羊を次式の係数 $\alpha$ で表す。

$$
q r=(I / \alpha S c)^{2}(P / S c)^{n} \cdot S c \cdot t i \cdot\left[1-\exp \left\{-d c^{2} /(16 \mathrm{k} \cdot t i)\right\}\right]
$$$$
\text { . . ( } 8 \text { ) }
$$

式(8)のメッキと非メッキの場合の係数であるが、メッキの溶ける領域の広 さで決まると考えられる。溶ける領域の広さは州㴟よりメッキの融点

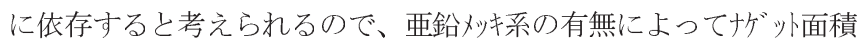

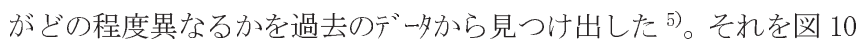
に示す。

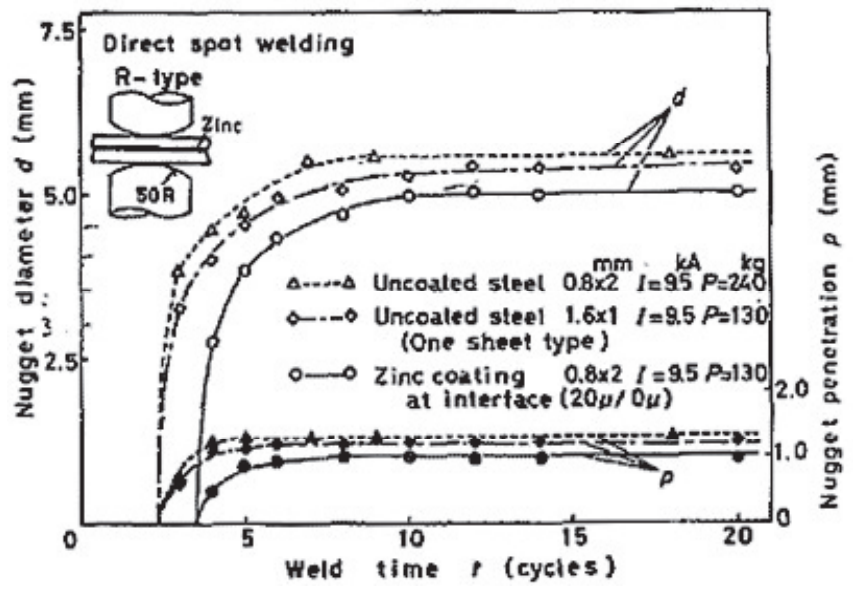

図 10 メッキの有無による暗゙ッ直径の差

図 10 で○印上 $\triangle$ 印を比較する。両者は電流が同じでナ师ト直径が

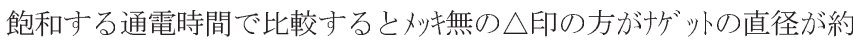
10\%増大している。新囬面積が 1.21 倍になっていることが解る。こ の竹”师面積の増大は電流密度の増大の起因するもの上考え、逆にメ 归の場合通電面積が大きくなり電流密度が低下したものと考え挦 の場合の係数を $\alpha=1.21$ とし、非州の場合を $\alpha=1.0$ と仮定する。 その妥当性は次節 3.2 で実証する。

\section{1.2 強度しベルも考慮した $q r$ の展開拡大}

図 9 に示寸発熱因子の説明図に戻って考える。図 9 の11電流密 度の項であるが、初期の板板間は塑性寸るほよ゙の荷重が作用してい ないので強度レベルが変わっても電流密度が変化しない。初期は確か に電流密度の差はないが、通電後接触部の温度が上昇すると塑性域 の広がりが強度い゙ルにより異なってくる。(2)の項は単位面積当たり の接触抵抗であるが、前述の温度上昇時の電流密度の差はあっても 単位面積当たりの接触抵抗に差はないであろう。(3)の項は通電され 加圧される領域に比例する量なので、初期の接触状態は強度い゙ルの 差に依存しないが、通電後の加熱時に強度い゙ルの低い場合は接触面 積が増えると仮定し通電域も加圧される面積も増えると仮定し強度 レ゙ルに依存する項と考える。最終項の通電終了後に $S c$ 内に残って いる熱量の割合を表すが、(3)項すなわち通電され加圧され溶接さ れる領域の残留する熱量の割合なので、強度レ゙ルに依存する。この ように考え、強度ル゙ルを考慮する係数べー夕を式(8)に加え次式のよう におく。

$$
\begin{gathered}
q r=(I / \alpha \cdot \beta \cdot S c)^{2}(P / S c)^{n} \cdot \beta \cdot S c \cdot t i \cdot \\
\text { ここで } \begin{array}{l|l|l|l|l|}
\multicolumn{2}{|c}{=18.2 \mathrm{~mm}^{2} / \mathrm{sec}} \\
\qquad \mathrm{t} & 1.6 & 2.3 & 3.2 & 4.5 \\
\hline \mathrm{n} & -3 / 4 & -1 / 2 & -1 / 3 & -1 / 4 \\
\hline \alpha: \text { 非妇の場合 } \alpha=1 \quad \text { 妙抽場合 } \alpha=1.21 \\
\beta=(400 \mathrm{~N} \text { 級の鋼板の引張規格強度 })
\end{array}
\end{gathered}
$$

\begin{tabular}{|c|l|l|l|l|}
\hline $\mathrm{t}$ & 1.6 & 2.3 & 3.2 & 4.5 \\
\hline $\mathrm{n}$ & $-3 / 4$ & $-1 / 2$ & $-1 / 3$ & $-1 / 4$ \\
\hline
\end{tabular}

(他の鋼種の引張規格強度)

式(9)に㧍いて $\beta$ として材料の引張強度規格值の比をとったのは 次のような理由である。

塑性域の大きさだと降伏点の比をとるのが筋であるが、降伏点は 
鋼材が圧延される場合の圧延度合い、冷却の仕方などで規格值以上 になるように品質管理される。これらが溶接熱により再加熱される とその効果は薄れる。それに比較して引張強度はそれらの影響を受 けにくいので、種々の鋼材への適用性を考え圧延度や冷却方法で影 響を受けないものとした。初期の板板間の接触は強度い゙ルの差を受 けないが、通電後の加熱時の強度いべル差で通電領域や加圧領域の 差が生じる。どの温度の強度レ゙ルでそれらが变わるか、また、それ らの温度依存性が解らないので、常温での引張強度の規格值の比を とった。これらの妥当性については次節 3.2 に示寸。

\section{2 発熱支配因子 $q r$ の非伂、異なる強度レベルの材料への展開 の妥当性の実証}

前節で抵抗溶接時の発熱支配因子の非抹材や強度しべルの異なる 材への展開の考え方について説明した、本節ではその妥当性を実験 により明らかにする。な㧍、試験体形状、寸法、供試材の機械的性 質、抵抗溶接諸条件は次章で述べる異なった板厚同士の組合せの場 合も示している。

\section{2. 1 実験条件}

（1）試験体形状、寸法、供試材料の機械的性質

実験に用いる試験体は前述の図 6 に示すもので、板厚の組合せと それらの寸法諸元を表 7 に示寸。

表 7 試験片寸法 (W, L, A, B \& \&図 6 参照)

\begin{tabular}{|c|c|c|c|c|}
\hline 板厚 $(\mathrm{mm})$ & 板幅(W) & 重ね代(L) & 試験片長さ(A) & クランフ間距離(B) \\
\hline $1.6 \times 1.6$ & 60 & 45 & 138 & 105 \\
\hline $2.3 \times 2.3$ & \multirow{5}{*}{90} & \multirow{5}{*}{60} & \multirow{5}{*}{160} & \multirow{5}{*}{120} \\
\hline $3.2 \times 3.2$ & & & & \\
\hline $4.5 \times 4.5$ & & & & \\
\hline $1.6 \times 3.2$ & & & & \\
\hline $1.6 \times 4.5$ & & & & \\
\hline
\end{tabular}

表 8 供試材料の機械的性質

\begin{tabular}{|c|c|c|c|c|}
\hline & 板厚 $(\mathrm{mm})$ & $\mathrm{Yp}(\mathrm{N} / \mathrm{mm} 2)$ & $\mathrm{Ts}(\mathrm{N} / \mathrm{mm} 2)$ & $\mathrm{EL}(\%)$ \\
\hline \multirow{3}{*}{ ZAM400 } & $\mathrm{t} 1.6$ & 349 & 467 & 34.2 \\
\cline { 2 - 5 } & $\mathrm{t} 2.3$ & 306 & 445 & 35.2 \\
\cline { 2 - 5 } & $\mathrm{t} 3.2$ & 304 & 455 & 36.5 \\
\cline { 2 - 5 } & $\mathrm{t} 4.5$ & 333 & 440 & 34.1 \\
\hline \multirow{2}{*}{ ZAM490 } & $\mathrm{t} 3.2$ & 429 & 568 & 26.1 \\
\cline { 2 - 5 } & $\mathrm{t} 4.5$ & 372 & 537 & 31.6 \\
\hline \multirow{3}{*}{ 非凶ッキ } & $\mathrm{t} 1.6$ & 293 & 428 & 40.0 \\
\cline { 2 - 5 } & $\mathrm{t} 2.3$ & 308 & 426 & 41.0 \\
\cline { 2 - 5 } & $\mathrm{t} 4.5$ & 290 & 421 & 47.0 \\
\hline
\end{tabular}

$400 \mathrm{~N} / \mathrm{mm}^{2}$ 鋼板でメッキ、非メッキのもの、メッキ材で $400 \mathrm{~N} / \mathrm{mm}^{2}$ と $490 \mathrm{~N} / \mathrm{mm}^{2}$ の材料を準備。使用材料の機械的性質を表 8 に示す。メッ †は溶融带鉛一6\%A1-3\%Mg 合金メッキ鋼板 (表中記号でZAM 上表示) で、 公称目付けが両面 $180 \mathrm{~g} / \mathrm{m}^{2}$, 最小目付け両面 $140 \mathrm{~g} / \mathrm{m}^{2}$ である。

\section{（2）抵抗溶接諸条件}

溶接機は前述した表 4、表 5 に示した 2 種の交流溶接機と電極を 用いた。溶接条件の水準は表 9 に示寸。
表 9 溶接条件水準

\begin{tabular}{|c|c|c|c|c|c|}
\hline 鋼種 & $\begin{array}{l}\text { 板厚 } \\
(\mathrm{mm})\end{array}$ & $\begin{array}{c}\text { 電極先端径 } \\
\text { ( } m m)\end{array}$ & $\begin{array}{l}\text { 電極先端単 } \\
\text { 位面積当の工 } \\
\text { 神 } \\
\left.\mathrm{s} / \mathrm{mA}^{2}\right)\end{array}$ & $\begin{array}{l}\text { 電極先端単 } \\
\text { 位面積当の } \\
\text { 加 压 力 } \\
(\mathrm{N} / \mathrm{mm} 2)\end{array}$ & $\begin{array}{l}\text { 溶 接 } \\
\text { 機·表 } \\
4,5 \text { 参 } \\
\text { 照 }\end{array}$ \\
\hline \multirow{2}{*}{$\begin{array}{l}\text { ZAM } \\
490\end{array}$} & $3.2 \times 3.2$ & $\phi 11,14$ & $2.6,3.3$ & 41,62 & \multirow[t]{2}{*}{ B } \\
\hline & $4.5 \times 4.5$ & 同上 & $3.2,4.0$ & 同上 & \\
\hline \multirow{4}{*}{$\begin{array}{l}\text { 非入师キ } \\
400\end{array}$} & $1.6 \times 1.6$ & $\phi 6,9$ & $0.7,0.9$ & 52,62 & \multirow[t]{2}{*}{$\mathrm{A}$} \\
\hline & $2.3 \times 2.3$ & 同上 & 同上 & 同上 & \\
\hline & 同上 & $\phi 11,14$ & $1.1,1.12$ & 41,62 & \multirow[t]{4}{*}{ B } \\
\hline & $4.5 \times 4.5$ & 同上 & $1.9,3.0$ & 同上 & \\
\hline \multirow{2}{*}{$\begin{array}{l}\text { ZAM } \\
400\end{array}$} & $1.6 \times 3.2$ & $\phi 9,11$ & $2.1,2.6$ & 62,70 & \\
\hline & $1.6 \times 4.5$ & 同上 & $2.2,2.6$ & 同上 & \\
\hline
\end{tabular}

$\mathrm{ZAM}$ : 溶融亜鉛- $6 \% \mathrm{Al}-3 \% \mathrm{Mg}$ 溶融妙持鋼板を表す 非吵：妙なしの黒皮除去した鋼板を表す $400: 400 \mathrm{~N} / \mathrm{mm}^{2}$ 級鋼を表す $490: 490 \mathrm{~N} / \mathrm{mm}^{2}$ 級鋼を表す

\section{3，2，2 実験結果および考察}

（1）メッキと非メッキの発熱因子の展開妥当性

$P u / \sigma u-q r$

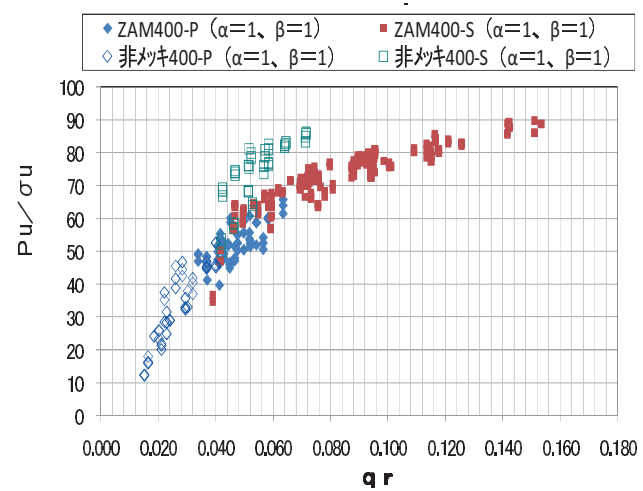

（a）式（3）のqrを用いた場合の引張せん断強度の整理

\section{$\mathrm{Pu} / \sigma \mathrm{u}-\mathrm{qr}$}

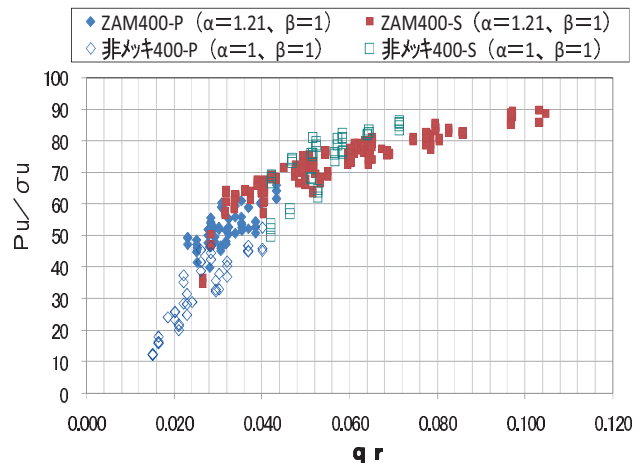

(b)式（9）のqrを用いた場合の引張せん断強度の整理

図 11 メッキ・非林への qrの展開妥当性の実証（板厚 2.3mm）

表 9 で示寸非桪 の同一板厚 $2.3 \mathrm{~mm}$ 同士の実験結果と前述した表 6 の梼の板厚 $2.3 \mathrm{~mm}$ の実験結果を従来の $q r$ の式 (3)（係数 $\alpha 、 \beta$ を 考慮しない式（3）=式（9）で $\alpha 、 \beta$ 上も 1 を代入したもの）で引 張せん断強度を整理したものを図 11 の (a) に示す。qrの值が 0.04

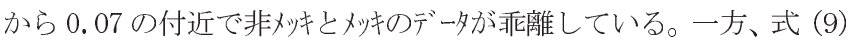




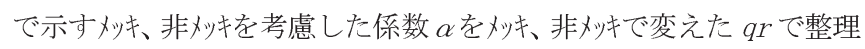
したのが図 1 1の（b）である。（a）で見られたような为、非炒 での乘離はない。表 9 で示す $1.6 \mathrm{~mm} 、 4.5 \mathrm{~mm}$ の板厚の場合も同様の効 果がみられた。図 11 以降類似兮うの縦軸 Pu/ ouの単位は $\mathrm{mm}^{2}$ 。

本章以降の実験結果と考察については、強度い゙ルを変えた材料で

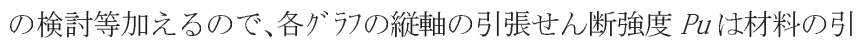
張強度汴一值 $\sigma u$ で除した值を用いる。

（2）強度レベルが異なる材料への発熱因子の展開妥当性

表 9 で示寸 $490 \mathrm{~N} / \mathrm{mm}^{2}$ 級州鋼板の同一板厚同士の板厚組合わせの 実験結果と表 6 で示した $400 \mathrm{~N} / \mathrm{mm}^{2}$ 級メッ捦岡板の実験結果をせん断強 度に関して式（3）で整理したものと式（9）で整理したものを比較 する。

実験は表 9 で示すように板厚 $3.2 \mathrm{~mm}$ 同士のもの上 $4.5 \mathrm{~mm}$ 同士のも のの 2 種を実施したが、傾向は変わらないので板厚 $3.2 \mathrm{~mm}$ 同士の板 厚の場合について比較を示す。

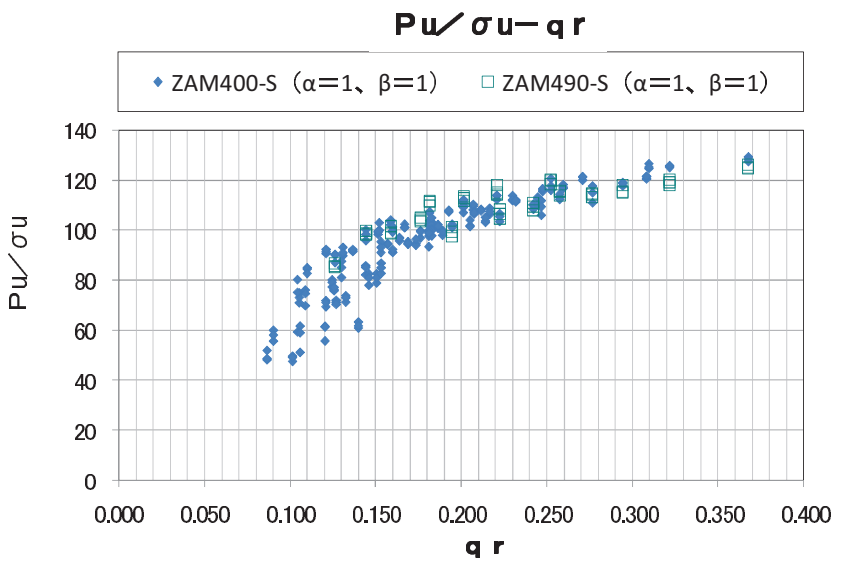

（a）式（3）のqrを用いた場合の引張せん断強度の整理

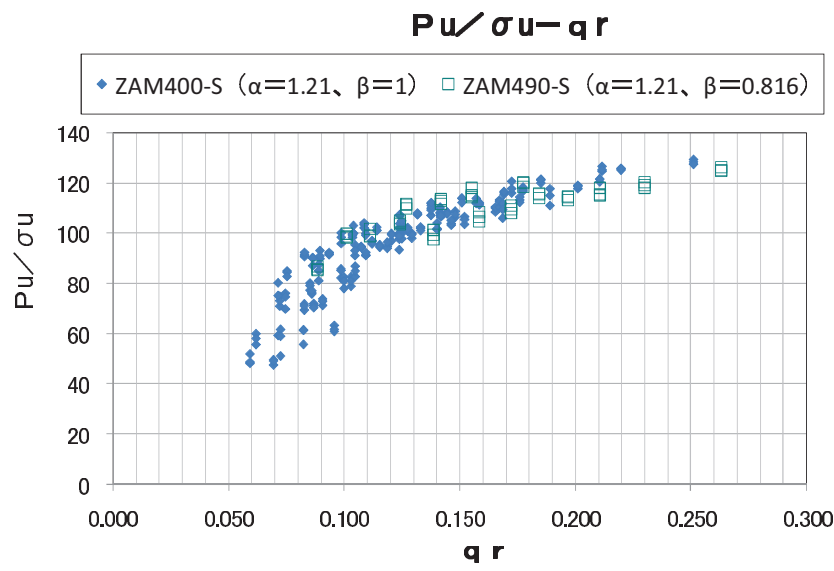

(b) 式（9）のqrを用いた場合の引張せん断強度の整理

図 12 強度の異なる鋼板への $q r$ の展開妥当性の実証（板厚 3. $2 \mathrm{~mm}$ )

図 12 の（a）と（b）を比較するとやや式(9)で整理した(b)の方が まとまりがあるように思えるが顕著な差はない。強度い゙ル温度依存 性やどの温度の強度差が効くのか不明なため、今後の研究に期待寸 るとして、発熱支配因子は式（9）のまま上する。

\section{4. 異なった板厚の抵抗溶接の場合}

前章までで、メッキ、非林、強度レベルの異なる同一板厚同士の抵抗溶 接の場合の引張せん断強度を支配寸る発熱因子 (式 (9)) について考 え方とその妥当性を検証してきた。

本章ではその発熱因子 (式 (9)) を異なる板厚の抵抗溶接に展開寸 る考え方とその妥当性検証をする。

\section{1 発熱支配因子 $q r$ の異なる板厚組合せの抵抗溶接への展開の 考え方}

式(3)式(9)に示した発熱支配因子の残留熱量の考え方は、電極軸 の方向に瞬間線熱源を投与したと考えて導いた式である。異なった 板厚の抵抗溶接で考慮されていない点は次の 2 点である。

図 13 で説明する。まず板厚 $t 1$ と $t 2$ を溶接する場合板厚に差があ れば、実際の溶接部は薄板 $t 1$ 同士の溶接よりも余分な熱量を消費 する。すなわち、溶接に寄与寸る発熱量は図 13 の（a）に示すより 少なくなる。この補正を熱量補正と呼ぶ。次の点は図 13 の (c)に 示すように実際の抵抗溶接では電極軸に垂直方向のみならず軸方向 にも熱が逃げていく為軸方向すなわち板厚方向への温度分布が生じ る。これで合計板厚中心の温度と溶接される界面の温度差ができ溶 融域の広さや最高温度の差が生じてくる。これを補正することを温 度分布補正と呼ぶ。

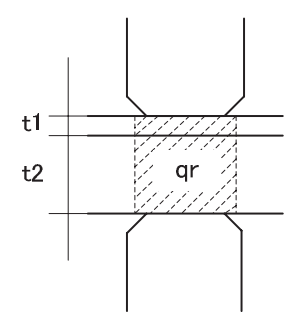

(a)瞬間線熱源に よる残留熱量から くる発熱因子qr

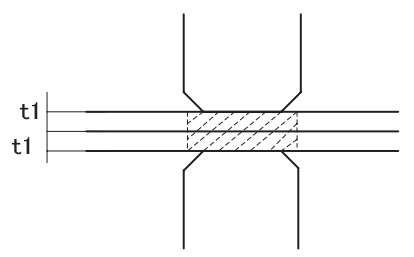

（b）溶接に寄与する熱量を考慮

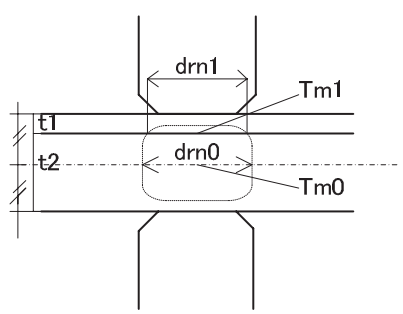

(c) 電極軸方向への温度分布考慮
図 13 発熱支配因子 $q r$ の補正（異なる板厚の場合）

板厚が異なる場合の抵抗溶接の溶融域のうち強度を確保する為の 必要溶融域は薄板側への板厚方向への梁さで充分であるう。したが って、熱量の補正としては次式となる。

熱量補正係数 $A=2 t 1 /(t 1+t 2) \quad \cdots(10)$

温度分布補正は次のように考える。

$t 1$ 上 $t 2$ の合計板厚上同じ同一板厚の抵抗溶接を想定して、温度 分布を考える。解析解として一般にあるものを適用して温度分布を 仮定する。すなわち、電極と板間は常に $0^{\circ} \mathrm{C}$ に維持され常に板板間 が発熱する場合の定常状態の温度と同じと仮定すると図 14 のよう に表され、板板間の温度を $T m O$ とすると電極板間を $0^{\circ} \mathrm{C}$ とした 2 次 
曲線で表される。式で表すと次式のようになる。 $T(z)=T m O\left(1-z^{2} / t 0^{2}\right) \quad t 0=(t 1+t 2) / 2 \cdots(11)$

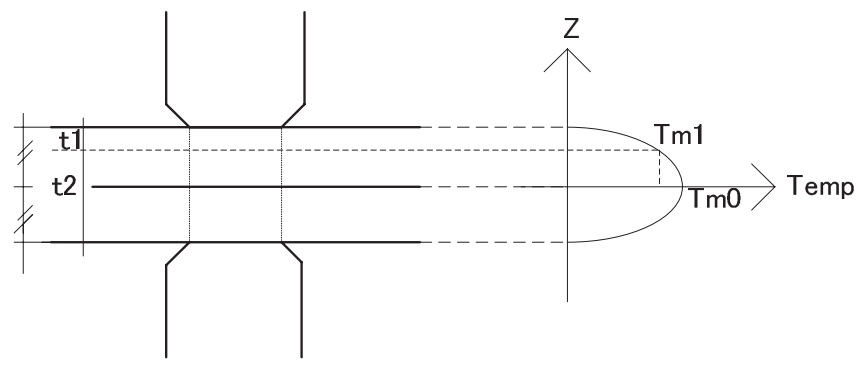

図 14 電極板間 $0^{\circ} \mathrm{C}$ 、板板間常発熱の定常温度分布

式(10)より合計板厚中心と板厚 $t 1$ と板厚 $t 2$ の界面の温度を合計 板厚中心の温度 $T m o$ の比 $B 1$ は次式上なる。これを温度上昇の補正係 数 $B 1$ とする。

$B 1=T m 1 / T m 0=1-\{(t 1+t 2) / 2-t 1\}^{2} /\{(t 1+t 2) / 2\}^{2} \cdots(12)$

次に、合計板厚中心の溶融域の直径 $d r n 0$ と板厚 $t 1$ と $t 2$ の界面の 溶融域の直径 $d r n 1$ の比を補正係数を考える。

溶融域の拡がりは最高到達温度が溶融温度以上となる領域である。 電極軸に仮に瞬間線熱源 $q m$ を投与した時の最高到達温度 T max は次 式(13)で表される。

$$
\begin{aligned}
& T \max =0.117(q \mathrm{~m} / \mathrm{c} \rho) / r^{2} \cdot \cdots(13) \\
& \text { ただし、 } \mathrm{c}: \text { 比熱 } \rho: \text { 密度 } r: \text { 熱源からの距離 }
\end{aligned}
$$

溶融温度を $T M$ としその時の熱源からの距離を $r m$ とすると次式 となる。

$$
r m^{2}=0.117(q \mathrm{~m} / \mathrm{c} \rho) \cdot T M \cdot \cdot(14)
$$

$r m$ r $d r n O / 2$ と $d r n / 2$ を代入しその時の仮の瞬間熱源投与量を $q m 0$ 上 $q m 1$ 上すると $d r n 0$ 上 $d r n 1$ の 2 乗の比は次式となる。

$$
(d r n 1 / d r n 0)^{2}=q m 1 / q m 0 \quad \cdots(15)
$$

$q m 1$ と $q m 0$ の比は、式(4)に示すように温度上昇に比例する。また、 式(12)の板厚 $t 1$ 上 $t 2$ の界面温度 $T m 1$ 上合計板厚中心の温度 $T m 0$ の比で表すと式(15)は次式（16）となる。これは板厚方向の温度分 布を電極軸に投与した仮の瞬間熱源投与に置き換えた他にならない。

$$
(d r n 1 / d r n O){ }^{2}=q m 1 / q m 0=T m 1 / T m O \cdot ・(16)
$$

式(16)は溶融面積の比になる。この溶融面積による補正係数を B2 とおく。すると、合計板厚中心上板厚 $\mathrm{t} 1$ 、 $\mathrm{t} 2$ の界面の温度上昇の補 整と溶融面積の補正を総合した補整係数 B は次式上なる。

$$
B=B 1 \times B 2=(T m 1 / T m O)^{2} \cdot \cdots
$$

以上の議論から、異なる板厚の場合の発熱支配因子は次式（18） のようになる。これを有効発熱因子 eqr 上呼ぶこととする。

eqr=qr$\cdot A \cdot B \quad \cdots(18)$

ただし、qr：式（9）A:式（10）B:式（17）

\section{2 発熱支配因子 $q r$ の異なる板厚同士の抵抗溶接への展開 の妥当性の実証}

\section{2, 1 実験条件}

試験体形状は前前章の図 6 に示したもので、その寸法、供試材料 の機械的性質は前章に示した表 7 と 8 の板厚 $1.6 \mathrm{~mm}$ と $3.2 \mathrm{~mm}$ おうよび $1.6 \mathrm{~mm}$ と $4.5 \mathrm{~mm}$ の組合せの $400 \mathrm{~N} / \mathrm{mm}^{2}$ 級州鋼である。

溶接諸条件の水準は表 9 の異板厚組合せの条件である。

\section{2.2 実験結果および考察}

実験結果を同一板厚での発熱支配因子 $q r($ 式(9)) で引張せん断強 度を整理したものと異板厚での有効発熱支配因子 $e q r($ 式(18))で整 理したものを比較するが、両式とも $q r$ の計算時に初期の板板間の接 触部の直径 $\mathrm{dc}$ をどう設定するか、接触抵抗に関する指数 $n$ をどう するかを次に検討する。

板板間の初期接触部の直径 $d c$ であるが、異なる板厚の場合加圧 時の両方の板の変形が接触部の直径に寄与寸ると考え平均的板厚を 式(7)に代入するか、薄板側の変形が大きいので、薄板側の板厚を代 入するかであるが、種々の板厚組合せで前者が式(7)によくマッチし た、その結果を図 15 に示す。図中の $d c 1$ は図 4,5 上同じ定義で $d c$ 式(3)、式(9)の $d c$ に対応するものである。

\section{de/t-dc1/t(t=t-ave)}

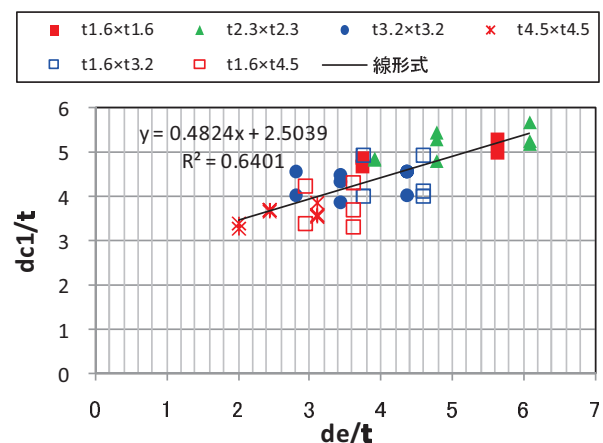

図 15 接触部の直径 $d c 1(=d c)$ と板厚 $\mathrm{t}$ との関係 $(t=(t 1+t 2) / 2$ の場合 $)$

接触抵抗に関連する指数 $n$ であるが、次のように考える。もとも と指数 $n$ は各板厚同士の抵抗溶接で引張せん断強度を整理するに適 した值を設定したので、同様に引張せん断強度が比較的よく整理で きるもの上して、次のように設定した。 $d c$ も示すと次式となる。

指数 $n=($ 板厚 $t 1$ 同士の係数 $n+$ 板厚 $t 2$ 同士の係数 $n) / 2$ $d c=0.5 d e+2.5 t \quad t=(t 1+t 2) / 2$ ・ ・ (19)

同一板厚同士の発熱支配因子 $q r$ で整理すると図 16 (a) のように なり、一本の曲線上にのっているとは言い難い。また、 $q r$ に補整係 数 $A$ のみをかけて整理しても図 16(b)のようになり一本の曲線上に 乗るとは言い難い。 


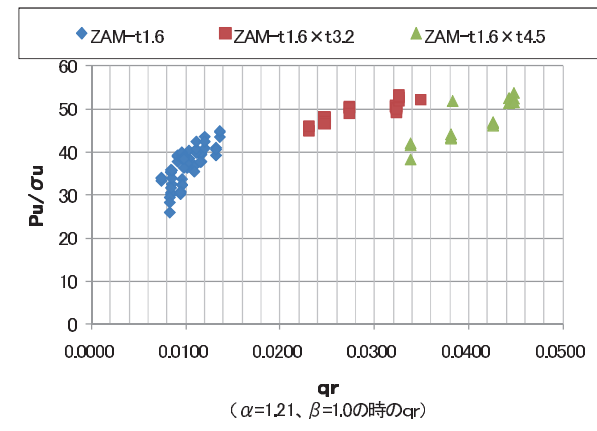

（a）式（9）による引張せん断強度の整理

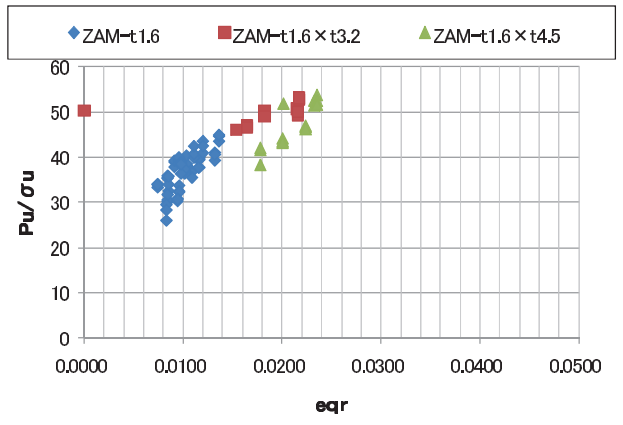

（b）式（9） $q r$ に補整係数 $A$ をかけて引張せん断強度 を整理した場合

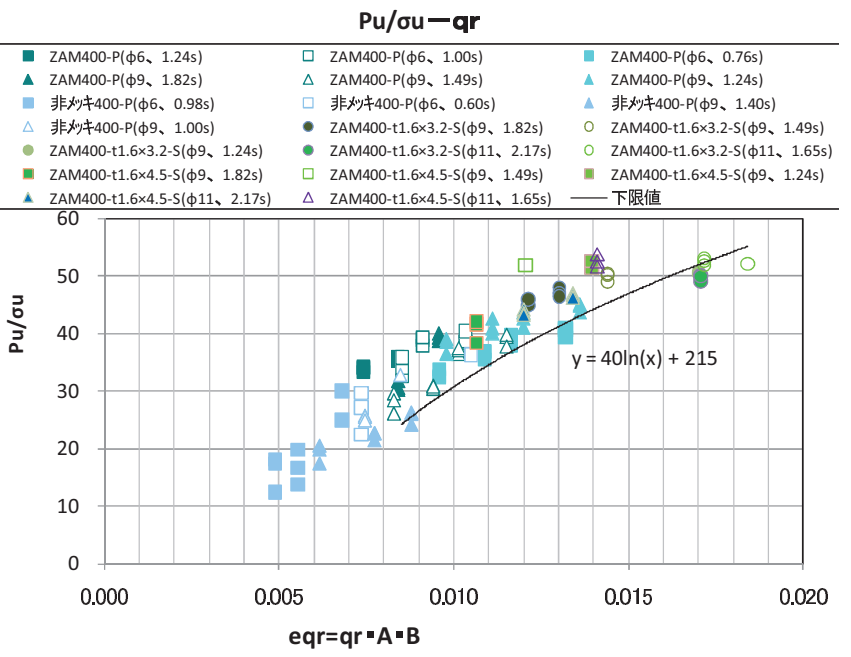

（c）式（9） $\operatorname{qr}$ に補整係数 $A$ と $B$ をかけた式（1 8) によ り引張せん断強度を整理した場合

図 16 異なる板厚で引張せん断強度の式（9）式（1 8) に よる整理の比較

図 16 （c）は式(9)の qr に補整係数 $A, B$ をかけた場合で䇸・非 メッキの場合の同一板厚 $1.6 \mathrm{~mm}$ の場合と薄板側板厚 $1.6 \mathrm{~mm}$ の異板厚の場 合のデータをプロッレている。種々のデータはうまく 1 本の曲線上に 乗っている。これは式(18)に示した異板厚の発熱支配因子の有効性 を示している。

\section{5. 引張せん断強度の発熱支配因子 eqr を利用した引張せん断強度 の実験式化と eqr の展開可能性}

(1) 実験式化

2 章〜 4 章で引張せん断強度への非メッキ・メッキの影響、強度レベルの影 響、板厚が異なる場合の影響を検討し、発熱支配因子 eqr で引張せ ん断強度が整理できることが明らかとなった。

2 章から 4 章のす心゙ての結果より、抵抗溶接の引張せん断強度を 発熱支配因子 eqr で整理した実験式を表 10 に示す。

表 10 引張せん断強度 $P u$ の発熱支配因子 $e q r$ による実験式化

\begin{tabular}{|c|c|c|c|}
\hline $\begin{array}{l}\text { 板厚組合 せ } \mathrm{t} 1 \mathrm{xt} 2 \\
(\mathrm{~mm} \cdot \mathrm{mm})\end{array}$ & $\begin{array}{r}\text { 電極先 } \\
\text { 端直径 } \\
(\mathrm{mm})\end{array}$ & $\begin{array}{l}\text { 発熱支配因子 eqr(式 (18)) } \\
\text { の適用範囲 }\left(\mathrm{N} / \mathrm{mm}^{2}\right) \mathrm{n} \cdot \\
\mathrm{KA}^{2} \cdot \mathrm{sec} / \mathrm{mm}^{2}\end{array}$ & $\begin{array}{l}\text { 引張せん䉼強度の実験式 } \\
\left(\mathrm{N} /\left(\mathrm{N} / \mathrm{mm}^{2}\right)=\mathrm{mm}^{2}\right)\end{array}$ \\
\hline $1.6 \times 1.6,2.3,3.2,4.5$ & $6 \sim 9$ & $0.008 \sim 0.0184$ & $\mathrm{Pu} / \sigma \mathrm{u}=40 \cdot \ln (\mathrm{eqr})+215$ \\
\hline $2.3 \times 2.3,3.2,4.5$ & $6 \sim 14$ & $0.03 \sim 0.105$ & $\mathrm{Pu} / \sigma \mathrm{u}=39.5 \cdot \ln (\mathrm{eqr})+177$ \\
\hline $3.2 \times 3.2,4.5$ & $9 \sim 14$ & $0.098 \sim 0.263$ & $\mathrm{Pu} / \sigma \mathrm{u}=50 \cdot \ln ($ eqr $)+195$ \\
\hline $4.5 \times 4.5$ & $9 \sim 14$ & $0.196 \sim 0.373$ & $\mathrm{Pu} / \sigma \mathrm{u}=108 \cdot \ln ($ eqr $)+270$ \\
\hline
\end{tabular}

表 11 溶接諸条件例

\begin{tabular}{|c|c|c|c|c|c|}
\hline 適用鋼種 & 板厚 $(\mathrm{mm})$ & $d e(\mathrm{~mm})$ & $P(\mathrm{~N})$ & $I(\mathrm{KA})$ & $t i(\mathrm{sec})$ \\
\hline \multirow{16}{*}{$\begin{array}{l}400,490 \\
\mathrm{~N} / \mathrm{mm} 2 \\
\text { 級州 }\end{array}$} & \multirow[t]{2}{*}{$1.6 \times 1.6$} & 6 & $1470 \sim 1740$ & $6.2 \sim 8.7$ & $1.24 \sim 0.76$ \\
\hline & & 9 & $3310 \sim 3920$ & $7.7 \sim 10.3$ & $1.82 \sim 1.24$ \\
\hline & \multirow[t]{4}{*}{$2.3 \times 2.3$} & 6 & $1470 \sim 1740$ & $6.2 \sim 8.7$ & $1.24 \sim 0.76$ \\
\hline & & 9 & $3310 \sim 4460$ & $7.7 \sim 11.9$ & $1.82 \sim 1.24$ \\
\hline & & 11 & $3920 \sim 6660$ & $9.6 \sim 15.5$ & $2.17 \sim 1.30$ \\
\hline & & 14 & $6350 \sim 10800$ & $11.8 \sim 19.0$ & $2.25 \sim 1.40$ \\
\hline & \multirow[t]{3}{*}{$3.2 \times 3.2$} & 9 & $3920 \sim 4460$ & $8.7 \sim 13.0$ & $1.82 \sim 1.24$ \\
\hline & & 11 & $3920 \sim 6660$ & $9.8 \sim 15.5$ & $2.17 \sim 1.30$ \\
\hline & & 14 & $6350 \sim 10800$ & $12.2 \sim 19.0$ & $2.25 \sim 1.40$ \\
\hline & \multirow[t]{3}{*}{$4.5 \times 4.5$} & 9 & $3920 \sim 4460$ & $8.3 \sim 13.5$ & $2.30 \sim 1.40$ \\
\hline & & 11 & $3920 \sim 6660$ & $9.5 \sim 14.5$ & $2.64 \sim 1.81$ \\
\hline & & 14 & $6350 \sim 10800$ & $12.6 \sim 18.5$ & $2.41 \sim 1.80$ \\
\hline & \multirow[t]{2}{*}{$1.6 \times 3.2$} & 9 & $3920 \sim 4460$ & $8.5 \sim 10.3$ & $1.82 \sim 1.24$ \\
\hline & & 11 & $4460 \sim 6660$ & $10.7 \sim 10.9$ & $2.17 \sim 1.65$ \\
\hline & \multirow[t]{2}{*}{$1.6 \times 4.5$} & 9 & $3920 \sim 4460$ & $8.7 \sim 10.6$ & $1.82 \sim 1.24$ \\
\hline & & 11 & $5850 \sim 6660$ & $9.8 \sim 11.2$ & $2.17 \sim 1.65$ \\
\hline
\end{tabular}

$d e$ :電極先端径 $I$ : 設定電流 $t i$ :通電時間 電極先端曲率半径 : $75 \mathrm{~mm}$

表 10 中 $\sigma \mathrm{u}$ は材料引張強度で泳一值を用いる。発熱因子 eqr は式 (18) で、各板厚や溶接条件を代入して求める。なお実験式は、各 eqr の下限レ゙ルを結んだ線である。eqr に適用範囲を設けたの壮次の理 由である。適用範囲より eqr の小さ側は同じ eqrでも溶接条件で 強度が多少異なり、下限レベルを設定しても過剩な条件設定上なる。 eqrの大きい側は表 10 に示した範囲外でも適用できると考えられる が、チリの発生など他の要因で溶接不可となると予想されたので実 験での上限範囲とした。なお、図 16 中の実線は表 10 の最上欄の薄 板側板厚 $1.6 \mathrm{~mm}$ の場合の実験式を表す。

表 10 を使うに当たり、実際どのような溶接条件範囲で eqr 設定 寸ればよいか解らないので、2 章から 4 章の実験で用いた溶接諸条 件を表 11 に示す。表 11 は 2 章から 4 章の寸べての実験での溶接諸 条件範囲なので表 10 で示した eqrの範囲外のものも含む(小さい側)。

表 10 の実験式は電極損傷を考慮したものではないので、実う们適 用時はこの実験式から求めた eqrの 20〜30\%増しの eqrに設定し実 ライで適用しながら電極交換またはドレッシ少間隔を決めればよい。 
（2）eqrの展開可能性

(1)（1）の実験式の適用範囲

【メッキ種について】

実験式は非メッキ黒皮なし、溶融亜鉛-6\%A1-3\%M g 合金メッ鋼板の実験 を基にしたものである。補正係数 $\alpha$ は烧融点に依存寸るので、融 点が大きく異なるメッ拴岡板には適用できない。よって、溶融亜鉛州、 溶融亜鉛-5\%A1 合金xッキ、溶融亜鉛-11\%A1-3\% M g - 0.2\% Si 合金xッキ等入 ッキの融点があまり変わらない犺まで適用拡大できる。

【鋼種について】

通常用いられる建築用の軟鋼・高張力鋼（50、60 吅鋼等）等の強 度の温度依存性の変化率があまり変わらなければ適用できると考え られる。接触面積はヤング率があまり変わらなければ影響うけない こと、熱拡散係数 $\mathrm{k}$ も変わらないことから推定される。ただ、耐火 鋼等は強度の温度依存性がこれらと異なるため適用には確認が必要 と思われる。

【板厚について】

溶接条件の目安を得るには実験式を $6 \mathrm{~mm}$ 厚程度まで拡大してもよ いと考えられるが、圧力の強さから接触抵抗に換算する時実験によ り指数 $n$ を求めているので、 $n$ を実験で求めるとより正確となる。

(2)eqrの展開

他の材料（化学組成、強度レ゙゙等）、板厚でも接触面積 $S c$ を板厚 と電極先端径で害験式化し, 接触抵抗を決める指数 $n$ を実験的に求 めれば溶接諸条件を統括して扱えるパラメー夕ーになる。㧊の補正係数 $\alpha$ も融点の異なる归種で検討すればより展開範囲は増える。

\section{6. まとめ}

（1）熱伝導の解析解に注目し、抵抗溶接の発熱支配因子 qr を明確 にし、同一板厚の $400 \mathrm{~N} / \mathrm{mm} 2$ 級の妙拴同で溶接後の引張せん断強度が うまく整理できることを明らかにした。

（2）発熱支配因子 $q r$ を非灯黒皮無し材、 $490 \mathrm{~N} / \mathrm{mm} 2$ への展開の考 え方を提案し、その妥当性を実験で明らかにした。

（3）異なった板厚への補整の考え方を提案し、それを発熱支配因子 eqr とし、その妥当性を実験で明らかにした。

(4)これらの結果を踏まえ、発熱支配因子 eqrを用いて抵抗溶接部 の引張せん断強度 Puを実験式化した。

この発熱支配因子 eqr を抵抗溶接条件パラメーターと呼ぶこととする。

\section{謝辞}

本研究は「市街地住宅等供給効率化事業」の一環であり、「建築用 薄板溶接接合部設計施工指針作成小委員会 (委員長 : 青木博文) /WG3(中込忠男)」の委員会活動上して実施したことを記して感謝の 意を表する。

\section{参考文献}

1）及川初彦他：鋼とアルミ方ムのスポット溶接に及ぼす各種因子の影響, 溶接学会 論文集, 第 14 巻, 第 2 号, pp267〜277, 1996

2）樺沢真事他：薄鋼板双ッ愹接継手の引張せん断強さの推定, 溶接学会論 文集, 第 14 巻, 第 4 号, pp754 761, 1996

3）佐久間康治他 : スポッ溶接部静的強度の支配因子とそれにもとづく溶接強 度特性の優れた高強度鋼板义二ュ一の展開, 新日鉄技報, 第 378 号, 2003

4）浜崎正信：重称抵抗溶接, 株式会社 産報, 1971

5）溶接学会抵抗溶接研究委員会：抵抗溶接現象とその応用（I） スポ
ツト溶接・下, 社団法人溶接学会, 1982

（2010年12月 8 日原稿受理，2011年 5 月23日採用決定） 